\title{
Comparison of the effect of meals and prostigmine on the proximal and distal colon in patients with and without diarrhoea
}

\author{
J. J. MISIEWICZ, A. M. CONNELL ${ }^{1}$, AND F. A. PONTES ${ }^{2}$ \\ From the Medical Research Council Gastroenterology Research Unit, \\ Central Middlesex Hospital, London
}

EDITORIAL COMMENT The right side of the colon tends to be relatively inaccessible to study. These observations, made by the telemetering technique of recording pressure, increase our knowledge of this region and show that activity on the right side of the colon tends to be independent of the activity in the sigmoid colon and rectum.

There are many reported studies of sigmoid and rectal motility, but less is known about the motility of the proximal colon, especially in the intact human. In this study intraluminal pressures in the proximal colon were recorded with an ingestible radio-telemetering capsule (Rowlands and Wolff, 1960; Connell, McCall, Misiewicz, and Rowlands, 1963) and compared with simultaneous pressure records from tubes introduced into the left colon. Patients with and without colonic disorders were studied in the basal state, after a meal and following parenteral prostigmine.

\section{PATIENTS STUDIED AND TECHNIQUE}

Twenty-two patients were studied, brief clinical details being shown in Table $I$. Cases 1 to 11 , with no symptoms referable to the colon, had a normal bowel habit and no abdominal pain at the time of the study; they were all in good general health. Cases 12 to 16 had the spastic colon syndrome, but were symptomless at the time of the study. Six other patients (nos. 17 to 22) had non-specific diarrhoea with or without left-sided abdominal pain and in all of these, symptoms were present at the time of study. All the diarrhoeal patients had a normal barium enema and faecal fat output and in none were pathogens found in the stools.

The radio-telemetering capsule was swallowed on the evening before the study together with a small quantity of barium; the following morning the capsule was localized by screening with an image amplifier. Additional information of value in localization came from the pressure record itself and from the estimation of the point of maximum signal strength in relation to the anterior abdominal wall. Intraluminal pressures from the left colon were recorded with $4 \times 7 \mathrm{~mm}$. air-filled rubber balloons, placed through a sigmoidoscope at 10 and $20 \mathrm{~cm}$.

'Present address: Department of Clinical Science, Queen's University, Belfast, Northern Ireland.

'In receipt of a grant from the Calouste Gulbenkian Foundation, Lisbon, Portugal. Present address: Estudos Gerais Universitarios, Luanda, Angola. from the anal margin and connected to transducers with fine polyethylene tubes (Fig. 1). Both the telemetering capsule and the balloons were calibrated in terms of centimetres of water pressure. Pressure tracings from the proximal and distal bowel were recorded simultaneously on a multi-channel pen writer. A stethograph was used in all the studies to monitor artefacts due to respiration or somatic movement.

\section{DESIGN OF STUDY AND ANALYSIS OF RECORDS}

The patients, who were fasting, rested comfortably on a couch in a quiet room and $\mathbf{3 0}$ minutes were allowed to

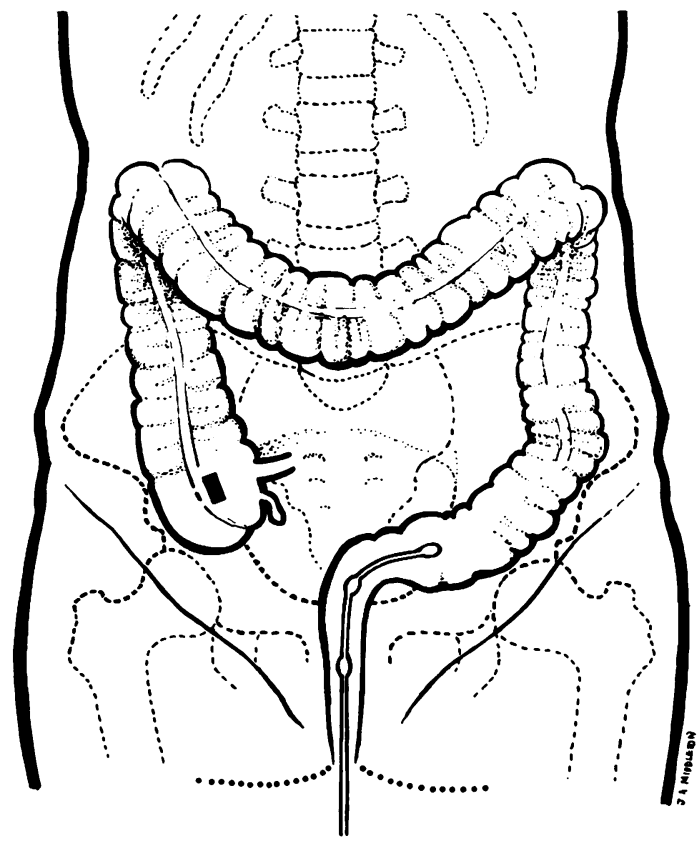

FIG. 1. The experimental situation. 
elapse following sigmoidoscopy before any observations were made. The basal motility of the colon was then recorded for 30 minutes and at the end of this period the patients ate a meal. Post-cibal activity was measured in the half-hour immediately following the meal. An intramuscular injection of $0.75 \mathrm{mg}$. of prostigmine was then given and, after an interval of 15 minutes, the effect of this drug on colonic motility was measured for a period of 30 minutes. At the end of the study the position of the radiopill was again found radiologically (Table I).

\section{TABLE I}

CLINICAL SUMMARY OF THE PRESENT SERIES

\begin{tabular}{|c|c|c|c|c|c|}
\hline \multirow[t]{2}{*}{ No. } & \multirow[t]{2}{*}{ Age } & \multirow[t]{2}{*}{$\operatorname{sex}$} & \multirow[t]{2}{*}{ Diagnosis } & \multicolumn{2}{|c|}{ Position of Radiopill } \\
\hline & & & & $\begin{array}{l}\text { Start of } \\
\text { Study }\end{array}$ & $\begin{array}{l}\text { End of } \\
\text { Study }\end{array}$ \\
\hline 1 & 22 & $\mathbf{M}$ & Duodenal ulcer & Caecum & Caecum \\
\hline 2 & 26 & $\mathbf{F}$ & Duodenal ulcer & Caecum & Caecum \\
\hline 3 & 45 & $\mathbf{M}$ & Duodenal ulcer & Caecum & $\begin{array}{l}\text { Ascending } \\
\text { colon }\end{array}$ \\
\hline 4 & 22 & $\mathbf{M}$ & Duodenal ulcer & Caecum & $\begin{array}{l}\text { Hepatic } \\
\text { flexure }\end{array}$ \\
\hline 5 & 40 & $\mathbf{F}$ & $\begin{array}{l}\text { Anorexia nervosa } \\
\text { in remission }\end{array}$ & Caecum & Caecum \\
\hline 6 & 57 & $\mathbf{F}$ & Diabetes mellitus & Caecum & Caecum \\
\hline 7 & 67 & $\mathbf{M}$ & Nephritis & Caecum & Caecum \\
\hline 8 & 52 & $\mathbf{M}$ & Diabetes mellitus & Caecum & Caecum \\
\hline 9 & 53 & $\mathbf{M}$ & Gastric ulcer & Caecum & Caecum \\
\hline 10 & 28 & $\mathbf{M}$ & Duodenal ulcer & $\begin{array}{l}\text { Rt } \\
\text { transverse }\end{array}$ & Rt \\
\hline 11 & 50 & $\mathbf{M}$ & Diabetes mellitus & $\begin{array}{l}\text { Calon } \\
\text { Caecum }\end{array}$ & $\begin{array}{l}\text { colon } \\
\text { Lt transverse } \\
\text { colon }\end{array}$ \\
\hline 12 & 24 & $\mathbf{F}$ & $\begin{array}{l}\text { Spastic colon } \\
\text { No symptoms }\end{array}$ & Caecum & Caecum \\
\hline 13 & 26 & $\mathbf{F}$ & $\begin{array}{l}\text { Spastic colon } \\
\text { No symptoms }\end{array}$ & Caecum & Caecum \\
\hline 14 & 41 & $\mathbf{F}$ & $\begin{array}{l}\text { Spastic colon } \\
\text { No symptoms }\end{array}$ & Caecum & $\begin{array}{l}\text { Rt transverse } \\
\text { colon }\end{array}$ \\
\hline 15 & 67 & $\mathbf{F}$ & $\begin{array}{l}\text { Spastic colon } \\
\text { No symptoms }\end{array}$ & Caecum & $\begin{array}{l}\text { Lt transverse } \\
\text { colon }\end{array}$ \\
\hline 16 & 47 & $\mathbf{F}$ & $\begin{array}{l}\text { Spastic colon } \\
\text { No symptoms }\end{array}$ & Caecum & Caecum \\
\hline 17 & 51 & $\mathbf{F}$ & Diarrhoea & Caecum & $\begin{array}{l}\text { Mid- } \\
\text { transverse } \\
\text { colon }\end{array}$ \\
\hline 18 & 40 & $\mathbf{F}$ & Diarrhoea & Caecum & $\begin{array}{l}\text { Ascending } \\
\text { colon }\end{array}$ \\
\hline 19 & 61 & $\mathbf{F}$ & Diarrhoea & Caecum & Caecum \\
\hline 20 & 59 & $\mathbf{F}$ & Diarrhoea & Right colon & $\begin{array}{l}\text { Splenic } \\
\text { flexure }\end{array}$ \\
\hline 21 & 59 & $\mathbf{M}$ & Diarrhoea & Caecum & $\begin{array}{l}\text { Splenic } \\
\text { flexure }\end{array}$ \\
\hline 22 & 46 & $\mathbf{F}$ & Diarrhoea & Caecum & $\begin{array}{l}\text { Rt transverse } \\
\text { colon }\end{array}$ \\
\hline
\end{tabular}

In each experimental period the duration of activity, defined as the percentage of the time of analysis during which pressure waves were present, was measured. In addition, the mean amplitude of the pressure waves in each experimental period was found. The total activity of the colon was expressed by the product of these two numbers. For the purpose of analysis the proximal colon was defined as lying proximal to the splenic flexure.

\section{RESULTS}

PRESSURE PATTERNS IN THE PROXIMAL AND DISTAL COLON The types of pressure waves previously described in the left colon (Connell, 1961) were also seen on the right side. Monophasic segmenting waves were recorded from both sides of the colon in all three experimental periods. The frequency of the contractions was often different in the distal and the proximal part of the large bowel. Rhythmic activity at the rate of approximately 2 per minute was seen more often in the sigmoid than in the caecum (Fig. 2).

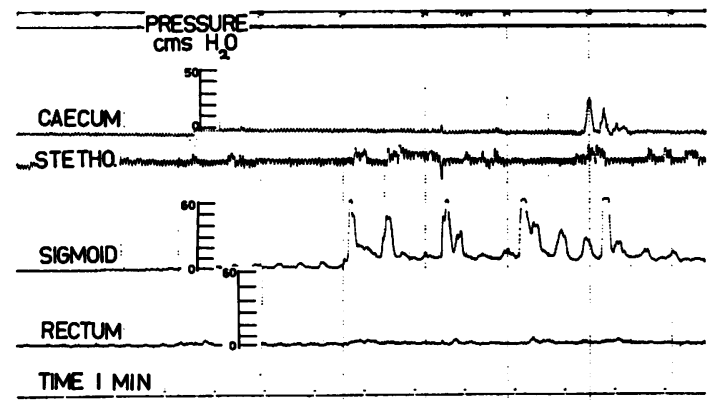

FIG. 2. Simultaneous intraliumnal pressure record from the right and left colon in a normal subject. Caecal pressure recorded with a telemetering capsule, sigmoid and rectal pressures with balloons.

Complex waves were recorded from both sides of the colon; an example from the hepatic flexure is illustrated in Figure 3. The administration of prostigmine sometimes resulted in intense activity at all the three recording points (Fig. 4).

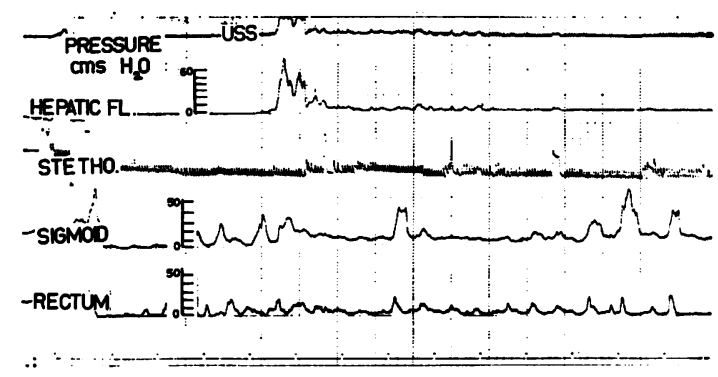

FIG. 3. Simultaneous pressure record from the hepatic flexure, sigmoid, and rectum.

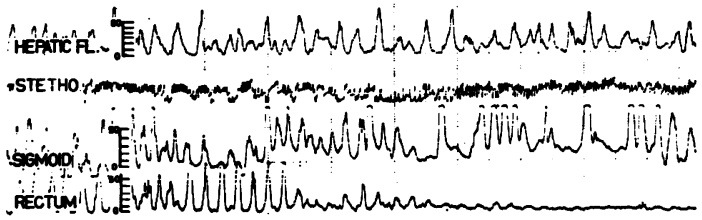

TIMEIMN

FIG. 4. Intraluminal pressures from the hepatic flexure, sigmoid, and rectum, following $0.75 \mathrm{mg}$. intramuscular prostigmine. 
TABLE II

PERCENTAGE DURATION OF ACTIVITY IN THE PROXIMAL COLON, SIGMOID, AND RECTUM

\begin{tabular}{|c|c|c|c|c|}
\hline & & \multirow{2}{*}{$\begin{array}{l}\text { No Colonic Symptoms } \\
\text { Mean (Range) S.D. }\end{array}$} & \multirow{2}{*}{$\begin{array}{l}\text { Diarrhoea } \\
\text { Mean (Range) }\end{array}$} & \multirow{2}{*}{$\begin{array}{l}\begin{array}{l}\text { Asymptomatic Spastic } \\
\text { Colon }\end{array} \\
\text { Mean (Range) }\end{array}$} \\
\hline & & & & \\
\hline Basal & $\begin{array}{l}\text { Proximal colon } \\
\text { Sigmoid } \\
\text { Rectum }\end{array}$ & $\begin{array}{l}24(0-67) \pm 22 \\
40(0-69) \pm 25 \\
34(0-77) \pm 20\end{array}$ & $\begin{array}{l}18(2-42) \\
14(0-33) \\
16(0-28)\end{array}$ & $\begin{array}{l}41(15-65) \\
59(6-90) \\
65(22-89)\end{array}$ \\
\hline After food & $\begin{array}{l}\text { Proximal colon } \\
\text { Sigmoid } \\
\text { Rectum }\end{array}$ & $\begin{array}{l}35(6-66) \pm 20 \\
51(16-91) \pm 24 \\
41(6-73) \pm 28\end{array}$ & $\begin{array}{l}12(0-22) \\
17(0-45) \\
24(2-67)\end{array}$ & $\begin{array}{l}47(24-63) \\
41(10-72) \\
39(27-56)\end{array}$ \\
\hline After prostigmine & $\begin{array}{l}\text { Proximal colon } \\
\text { Sigmoid } \\
\text { Rectum }\end{array}$ & $\begin{array}{l}45(6-95) \pm 28 \\
79(32-100) \pm 23 \\
73(23-100) \pm 24\end{array}$ & $\begin{array}{l}64(33-85) \\
70(40-91) \\
69(37-97)\end{array}$ & $\begin{array}{l}83(75-100) \\
72(63-87) \\
88(70-100)\end{array}$ \\
\hline
\end{tabular}

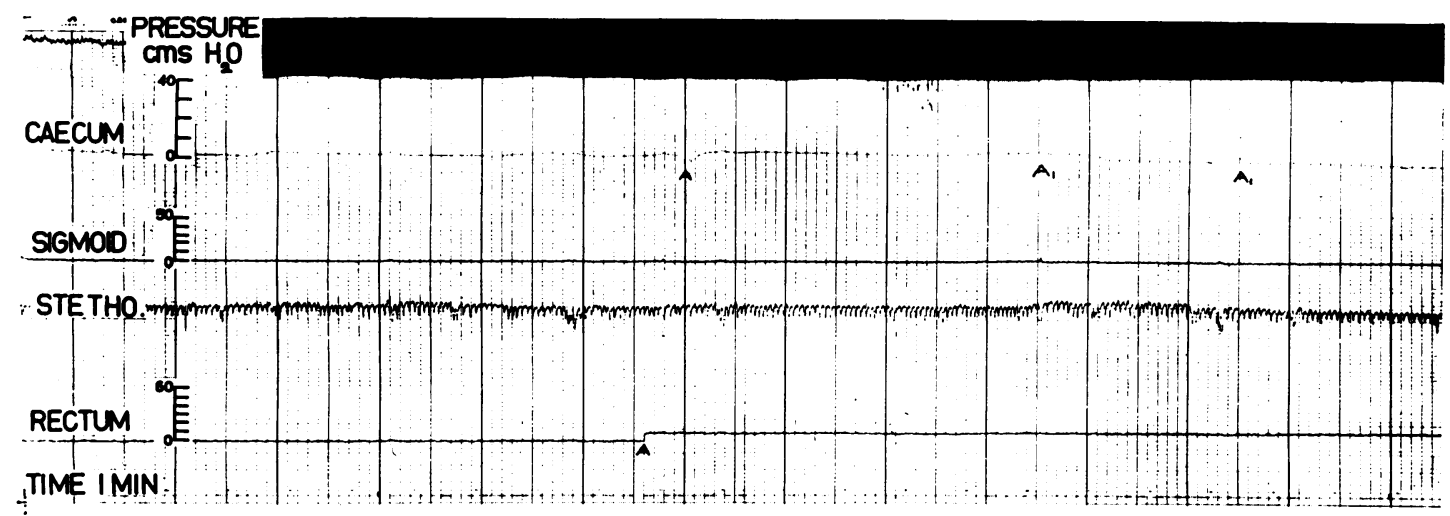

FIG. 5. Record over $20 \mathrm{~min}$. from the right and left colon of a patient with severe functional diarrhoea $(A=$ artefacts $)$. Striking lack of segmental contractions in the caecum, sigmoid, and the rectum.

PERCENTAGE DURATION OF ACTIVITY IN THE PROXIMAL AND DISTAL COLON The percentage duration of activity in the proximal and distal colon in the basal, post-cibal and post-prostigmine periods is shown in Table II. Patients with diarrhoea at the time of study tended to have less activity in both the proximal and the distal colon than patients in the other two groups. A 20-minute length of a basal record from such a patient is shown in Figure 5. The response of diarrhoeal patients to a meal also tended to be less. After injection of prostigmine, there was little difference in the duration of activity between the three groups.

MEAN AMPLITUDE OF PRESSURE WAVES IN THE PROXIMAL AND DISTAL COLON Table III shows the mean amplitude of the pressure waves in the proximal and distal colon. There appeared to be little difference in the mean amplitude of pressure waves between the proximal and distal colon in the basal state. The

TABLE III

MEAN AMPLITUde OF PRESSURE PEAKS IN THE PROXIMAL COLON, SIGMOID, AND RECTUM

\begin{tabular}{|c|c|c|c|c|}
\hline & & \multirow{3}{*}{$\begin{array}{l}\text { No Colonic Symptoms } \\
\text { Mean (Range) S.D. } \\
\left(\mathrm{cm} . \mathrm{H}_{2} \mathrm{O}\right)\end{array}$} & \multirow{3}{*}{ 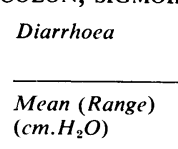 } & \multirow{3}{*}{$\begin{array}{l}\begin{array}{l}\text { Asymptomatic Spastic } \\
\text { Colon }\end{array} \\
\begin{array}{l}\text { Mean }(\text { Range }) \\
\left(\mathrm{cm} . \mathrm{H}_{2} \mathrm{O}\right)\end{array}\end{array}$} \\
\hline & & & & \\
\hline & & & & \\
\hline Basal & $\begin{array}{l}\text { Proximal colon } \\
\text { Sigmoid } \\
\text { Rectum }\end{array}$ & $\begin{array}{r}7 \cdot 9(0 \cdot 0-21 \cdot 5) \pm 6 \cdot 8 \\
10 \cdot 0(0 \cdot 0-18 \cdot 0) \pm 5 \cdot 6 \\
6 \cdot 0(0 \cdot 0-11 \cdot 6) \pm 3 \cdot 2\end{array}$ & $\begin{array}{l}9 \cdot 1(3 \cdot 0-22 \cdot 0) \\
9 \cdot 4(0.0-17 \cdot 4) \\
6 \cdot 6(0 \cdot 0-11 \cdot 4)\end{array}$ & $\begin{array}{r}9 \cdot 9(5 \cdot 0-17 \cdot 6) \\
13 \cdot 4(9 \cdot 2-17 \cdot 4) \\
11 \cdot 1(7 \cdot 8-13 \cdot 5)\end{array}$ \\
\hline After Food & $\begin{array}{l}\text { Proximal colon } \\
\text { Sigmoid } \\
\text { Rectum }\end{array}$ & $\begin{array}{r}13 \cdot 8(6 \cdot 7 \cdot 21 \cdot 6) \pm 5 \cdot 2 \\
19 \cdot 0(8 \cdot 5 \cdot 37 \cdot 5) \pm 8 \cdot 4 \\
8 \cdot 8(4.9-21 \cdot 8) \pm 5 \cdot 3\end{array}$ & $\begin{array}{l}9 \cdot 0(0 \cdot 0-18 \cdot 3) \\
9 \cdot 6(0 \cdot 0-14 \cdot 9) \\
9 \cdot 1(5 \cdot 0-14 \cdot 1)\end{array}$ & $\begin{array}{r}11 \cdot 7(5 \cdot 6-21 \cdot 8) \\
13 \cdot 5(9 \cdot 2-16 \cdot 5) \\
8 \cdot 4(7 \cdot 6-11 \cdot 0)\end{array}$ \\
\hline After Prostigmine & $\begin{array}{l}\text { Proximal colon } \\
\text { Sigmoid } \\
\text { Rectum }\end{array}$ & $\begin{array}{l}18 \cdot 0(6 \cdot 7-21 \cdot 6) \pm 7 \cdot 9 \\
22 \cdot 2(14 \cdot 4-27 \cdot 7) \pm 8 \cdot 2 \\
12 \cdot 7(5 \cdot 4-26 \cdot 7) \pm 6.1\end{array}$ & $\begin{array}{l}13 \cdot 2(9 \cdot 3-27 \cdot 0) \\
26 \cdot 2(12 \cdot 8-38 \cdot 7) \\
13 \cdot 6(8 \cdot 6-21 \cdot 0)\end{array}$ & $\begin{array}{l}21 \cdot 3(13 \cdot 9-27 \cdot 6) \\
14.9(11 \cdot 0-31 \cdot 5) \\
11 \cdot 8(10 \cdot 0-17 \cdot 3)\end{array}$ \\
\hline
\end{tabular}


height of the pressure waves tended to rise following a meal in the asymptomatic patients. There was an increase in the mean amplitude of the pressure waves in all three groups of patients following the injection of prostigmine.

COMPARISON OF TOTAL ACTIVITY OF THE PROXIMAL AND DISTAL COLON IN INDIVIDUAL PATIENTS IN THE BASAL STATE, AFTER A MEAL, AND AFTER PROSTIGMINE The pressure activity in the proximal colon was found to occur independently from the activity of the sigmoid or of the rectum. Figure 6 compares total basal activity in the proximal and the sigmoid colon of each patient in the three diagnostic groups. The level of activity on the right side correlated poorly with the activity on the left side. In some patients there was considerable activity in the distal colon with none in the proximal and vice versa. In the diarrhoeal group, activity was low on both sides, but again considerable variations may occur.

Figure 7 shows the difference in activity from basal values following the ingestion of food. In general, colonic activity increased in symptomless patients and this was more apparent in the distal than in the proximal colon. In patients with the irritable bowel syndrome or diarrhoea the meal did not produce any clear-cut effect in the motor activity on either the right or the left side of the colon.

Figure 8 shows the differences in activity from basal values following the injection of $0.75 \mathrm{mg}$. of

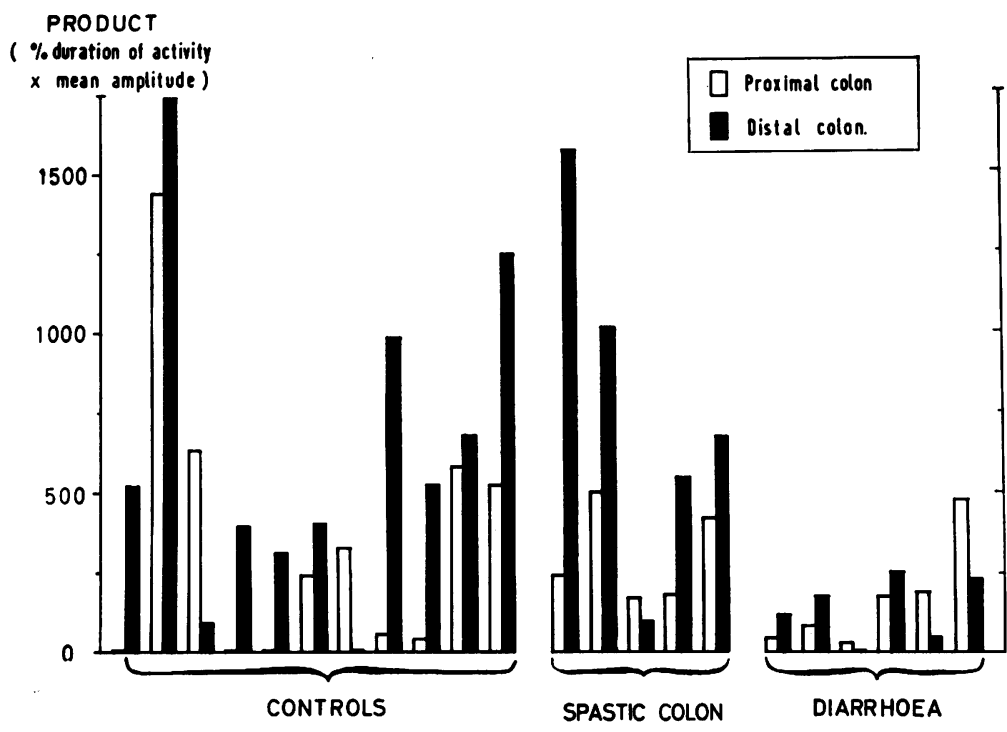

FIG. 6. Activity of the proximaland distal colon in individual patients during the basal period. A result from the proximal and distal colon is shown for each patient, but the activity was almost zero in three proximal and two distal records.

PRODUCT

( $\%$ duration of activity

$x$ mean amplitude)

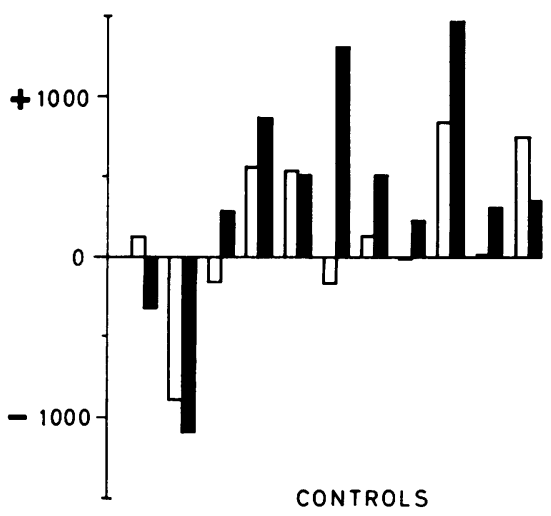

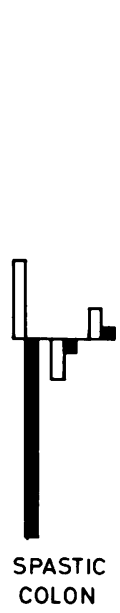
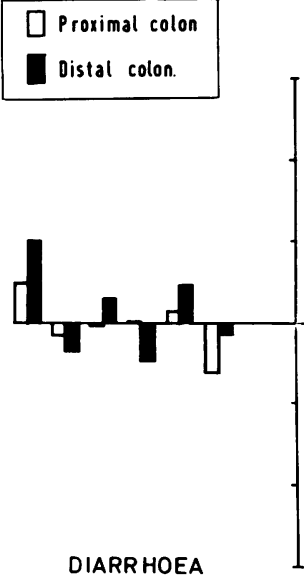

FIG. 7. Activity of the proximal and distal colon in individual patients following a meal. Results expressed as a difference from the basal value. 


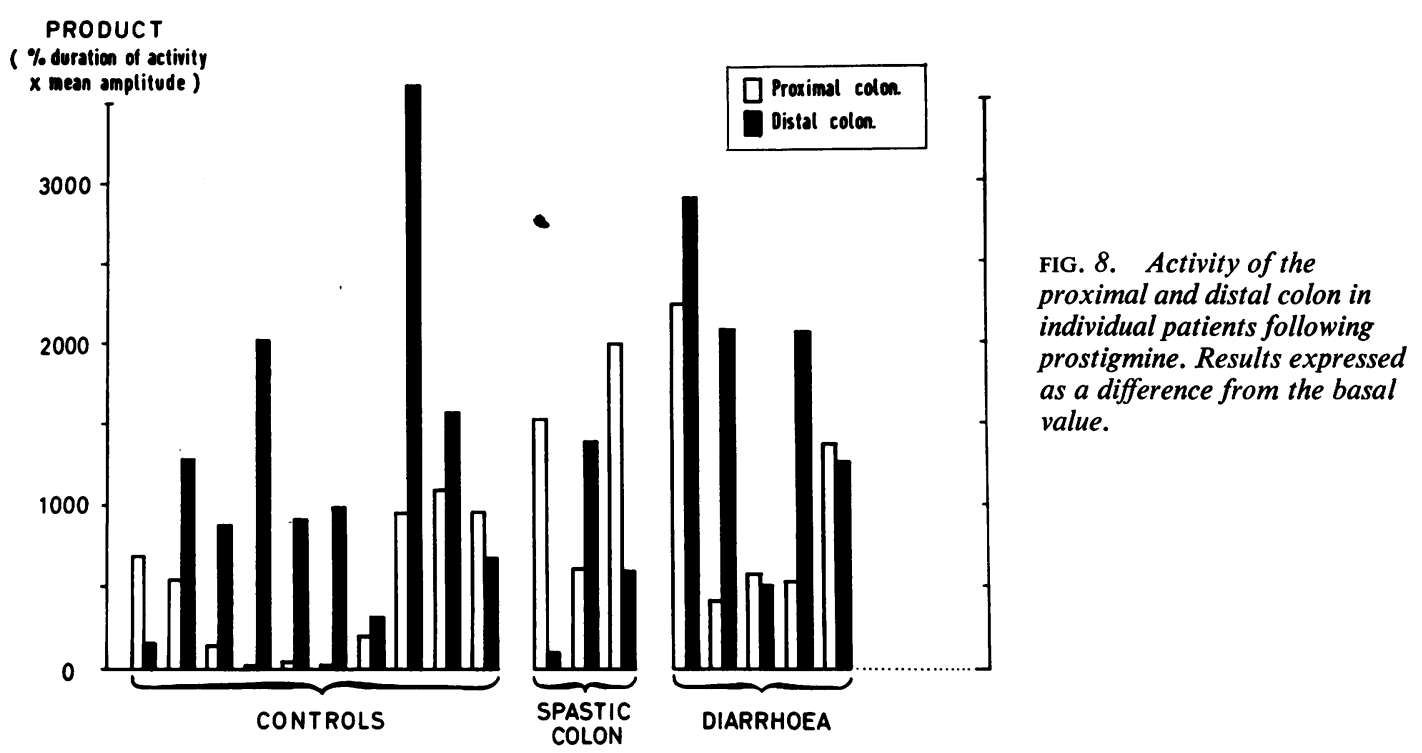

prostigmine. There was a net increase of activity above the basal values on both sides of the colon in the three groups of patients. Sigmoid activity increased in all of the 18 patients who were given the drug and with only three exceptions there was an increase in activity of the proximal colon as well. The magnitude of the response to prostigmine varied on the two sides, but in 12 of the 18 patients the response was greater in the left than in the right colon.

Propulsion of the radiopill along the colon occurred more frequently in the diarrhoeal patients than in others. The radiopill moved distally during the study in five of the six diarrhoeal patients, but its position was unchanged in 11 of 16 patients in the other two groups (Table I). It was our impression that this movement of the capsule took place chiefly after the injection of prostigmine.

\section{DISCUSSION}

The methods of pressure recording employed for comparison of the two sides of the colon were not identical, but there is evidence that the results are comparable, as a miniature balloon gives similar qualitative results to those obtained by a radiopill (Connell and Rowlands, 1960). The height of the pressure waves and their configuration were similar in the proximal and the distal large bowel.

The main conclusion of this study is that the patterns of activity of the right and left colon were different at any one time. This finding supports the concept that pressure waves recorded from the lumen

of the colon represent segmenting contractions. The dissociation of activity on the right and left side confirms the findings of Fink and Friedman (1960) who used a transtubation technique. Wangel and Deller (1965) employed a technique similar to ours for the simultaneous study of proximal and distal colonic motility. Four of their subjects who had a normal bowel habit tended to have more activity on the right than on the left, while in a constipated patient the opposite was observed. One diarrhoeal patient showed a gradient of activity from right to left. Our data do not appear to provide evidence for the existence of a pressure gradient between the two sides of the colon.

The effect of food on the proximal and distal colon was variable and produced a modest rise in activity or even a depression below the basal values. The response to prostigmine was more uniform and resulted in a rise of activity on both sides of the colon in almost all the subjects. This response was more marked on the left side.

Hypomotility of the sigmoid colon in diarrhoeal patients in this series confirms the previous finding of low levels of activity associated with frequent bowel actions (Connell, 1962; Wangel and Deller, 1965). This hypomotility may at times affect the whole colon, but as very low levels of activity have also been observed on the right side in the symptomless group, the significance of this observation remains doubtful. The response of the diarrhoeal group to prostigmine results in total activity of the same order as that found in the symptomless group. 
SUMMARY

A combination of radiotelemetering and intubation techniques was used to measure intraluminal pressure simultaneously in the proximal and distal colon of patients with the irritable bowel syndrome, functional diarrhoea, and a control group. Symptoms were present at the time of study in the diarrhoeal patients, but not in the irritable bowel group.

The pressure waves in the proximal colon were generally similar in type and magnitude to those in the distal colon, but in any one patient the level and pattern of activity on the two sides could vary widely.

The hypomotility of the pelvic colon in diarrhoea could also extend to the proximal colon. The effect of food on colonic motility was variable, but both sides of the colon showed increased activity after prostigmine in all three groups of patients.

\section{REFERENCES}

Connell, A. M. (1961). The motility of the pelvic colon. I. Motility in normals and in patients with asymptomatic duodenal ulcer. Gut, 2, 175-186.

(1962). The motility of the pelvic colon. II. Paradoxical motility in diarrhoea and constipation. Gut, 3, 342-348.

- and Rowlands, E. N. (1960). Wireless telemetering from the digestive tract .Gut, 1, 266-272.

- McCall, J., Misiewicz, J. J., and Rowlands, E. N. (1963). Observations on the clinical use of radio pills. Brit. med. J., 2 771-774.

Fink, S., and Friedman, G. (1960). The differential effect of drugs on the proximal and distal colon. Amer. J. Med., 28, 534-540.

Rowlands, E. N., and Wolff, H. S. (1960). Brit. Commun. Electron., 7, 598-601.

Wangel, A. G., and Deller, D. J. (1965). Intestinal motility in man. III. Mechanisms of constipation and diarrhea with particular reference to the irritable colon syndrome. Gastroenterology, 48, 69-84. 